\title{
Tid er hjerne - også når det bakre kretsløp rammes
}

\author{
Hjerneinfarkt i forsyningsområdet til det bakre kretsløpet har uspesifikke symptomer og kan være en \\ diagnostisk utfordring. For å sikre flere optimal behandling må kunnskapen om symptomene økes både \\ i befolkningen og blant helsepersonell.
}

Ca. $80 \%$ av hjerneslag er iskemisk betinget og kan oppstå i forsyningsområdene til fremre kretsløp (forsyningsområdet til arteria carotis, arteria cerebri media og arteria cerebri anterior) og bakre kretsløp (forsyningsområdet til arteria cerebri posterior, arteria vertebralis og arteria basilaris). Sistnevnte utgjør ca. $20 \%$ av tilfellene (1) og har mer uspesifikke symptomer enn hjerneslag i fremre kretsløp. Derfor kan disse være en betydelig diagnostisk utfordring som kan føre til forsinket diagnostikk og akuttbehandling.

Ved akutt iskemisk hjerneslag kan vi tilby tre kunnskapsbaserte behandlinger (2): Behandling i slagenhet, acetylsalisylsyre i metningsdose og intravenøs trombolytisk behandling hvis gitt innen 4,5 timer etter symptomdebut, og i enkelte tilfeller vil også intraarteriell intervensjon være aktuelt. Jo raskere denne behandlingen gis, desto bedre prognose.

Iskemi i forsyningsområdet til a. cerebri posterior gir hos $90 \%$ synsfeltforstyrrelse og hos rundt én av tre kontralaterale sensibilitetsforstyrrelser (3). Iskemi i forsyningsområdet til det vertebrobasilære kretsløpet kan gi varierende grad av vertigo, kvalme, nystagmus, hodepine og hjernestammesymptomer som orofaryngeal dysfunksjon, okulomotoriske forstyrrelser, ataksi, bevissthetsforstyrrelser, sensibilitetsforstyrrelser og redusert kraft i ekstremitetene (4).

De vanligste symptomene på iskemi i bakre kretsløp er imidlertid svimmelhet, unilateralt redusert kraft i ekstremitetene, ataksi, dysartri, hodepine og kvalme (4). Svimmelhet, kvalme og oppkast er uspesifikke symptomer og kan forekomme ved en rekke tilstander som f.eks. perifer vertigo eller gastroenteritt. Flere studier har vist at kvalme og oppkast som symptomer ved cerebrovaskulær årsak ofte forsinker både utredning og tid til oppstart av behandling (5).

\section{For lite kunnskap i befolkningen}

Tid fra symptomdebut til terapi ved akutt hjerneinfarkt er essensielt for prognosen. For å komme raskt til sykehus må symptomene på hjerneslag gjenkjennes og alarmeres. Halvparten av alle med akutt hjerneslag kommer for sent til sykehus for å få trombolytisk behandling (6). Det er vist at det fremdeles er manglende kunnskap om både risikofaktorer og symptomer på hjerneslag i befolkningen (7).

Arbeidet med folkeopplysning er de siste årene blitt mer prioritert. Her i landet har vi ikke hatt noen ensartet nasjonal informasjonskampanje, men isteden ulike parallelle kampanjer: SOS hjerneslag (Norsk Luftambulanse), SMIL (Helse Vest), SLAG

\section{«Det er et stort behov for en samordnet nasjonal informasjons-
kampanje»}

(Språk, Lammelse, Ansikt, Gangvansker; Folkeopplysning om hjerneslag) og den norske utgaven av FAST (Fjes, Arm, Språk, Tale; Helsedirektoratet).

Ingen av disse kampanjene fanger opp alle symptomer ved slag generelt og spesielt ikke fra forsyningsområdet til det bakre kretsløp. Dette gjenspeiles blant annet i tallene fra Norsk hjerneslagregister, der $20 \%$ av pasientene med hjerneslag ikke har FAST-symptomer når de ankommer sykehus (6).

Vi mener det er et stort behov for en samordnet nasjonal informasjonskampanje for å øke kunnskapen om risikofaktorer og symptomer på hjerneslag og om hvordan man skal handle dersom man blir rammet.

\section{Diagnostiske utfordringer}

National Institutes of Health Stroke Scale (NIHSS) brukes for kartlegging av nevrologiske utfall og utgjør en del av grunnlaget ved valg av behandling ved akutte hjerneslag. Skalaen er vektet mer mot slag i forsyningsområdet til det fremre kretsløpet (8). Den gir høyest skår ved motoriske og kortikale symptomer, noe lavere skår ved ekstremitetsataksi og hjernenerveutfall, mens trunkal ataksi og nystagmus ikke gir poeng.

$\mathrm{CT}$ caput med eller uten kontrast er et utilstrekkelig verktøy for å utelukke iskemi i forsyningsområdet til det bakre kretsløpet. Diffusjonsvektet MR foretrekkes og regnes som gullstandarden (1). Det er dessverre kun et fåtall av de største sykehusene som tilbyr MR-undersøkelse i akuttfasen. Oftest står vi igjen med en vanskelig klinisk vurdering der minuttene teller.

Vi har i dag ikke gode tall på andelen som får trombolytisk behandling ved bakre kretsløpsinfarkt i Norge, men det er færre enn blant dem som har hjerneinfarkt i forsyningsområdet til det fremre kretsløpet (5). Pasienter med bakre kretsløpsinfarkt blir ofte for sent identifisert og er gjennomsnittlig yngre enn andre pasienter med akutt iskemisk slag $(9,10)$.

Kunnskapen om symptomer på hjerneslag generelt, og i forsyningsområdet til det bakre kretsløpet spesielt, både i befolkningen og blant helsepersonell må økes, slik at pasientene kommer til sykehus så raskt som mulig etter symptomdebut. Bare da vil vi være i stand til å gi optimal behandling for å begrense nevrologisk sekvele og bevare hjernen best mulig.

\section{Håkon Ihle-Hansen \\ haaihl@vestreviken.no \\ Guri Hagberg \\ Bente Thommessen \\ Hege Ihle-Hansen}

Håkon Ihle-Hansen (f. 1984) er lege i spesialisering ved Medisinsk avdeling og ph.d.-stipendiat ved Forskningsavdelingen, Bærum sykehus, Vestre Viken.

Forfatter har fylt ut ICMJE-skjemaet og oppgir ingen interessekonflikter.

Guri Hagberg (f. 1979) er lege i spesialisering og ph.d.-stipendiat ved Seksjon for geriatri, slag og rehabilitering, Medisinsk avdeling, Bærum sykehus, Vestre Viken.

Forfatter har fylt ut ICMJE-skjemaet og oppgir ingen interessekonflikter.

Bente Thommessen (f. 1954) er dr.med. og overlege ved Nevroklinikken, Akershus universitetssykehus.

Forfatter har fylt ut ICMJE-skjemaet og oppgir ingen interessekonflikter.

Hege Ihle-Hansen (f. 1970) er ph.d., overlege ved Seksjon for geriatri, slag og rehabilitering, Medisinsk avdeling og postdoktor ved Forskningsavdelingen, Bærum sykehus, Vestre Viken. Hun er medlem i utvalget som reviderer nasjonale retningslinjer for hjerneslag.

Forfatter har fylt ut ICMJE-skjemaet og oppgir ingen interessekonflikter. 


\section{Litteratur}

1. Savitz SI, Caplan LR. Vertebrobasilar disease. N Engl J Med 2005; 352: 2618-26.

2. Hjerneslag. Nasjonal faglig retningslinje for behandling og rehabilitering ved hjerneslag. https://helsedirektoratet.no/retningslinjer/ nasjonal-faglig-retningslinje-for-behandling-og rehabilitering-ved-hjerneslag (27.4.2015)

3. Masuhr KF, Neumann M. Neurologie: 128 Tabellen. Stuttgart: Georg Thieme Verlag, 2007: 392.

4. Searls DE, Pazdera L, Korbel E et al. Symptoms and signs of posterior circulation ischemia in the new England medical center posterior circulation registry. Arch Neurol 2012; 69: 346-51.

5. Sarraj A, Medrek S, Albright K et al. Posterior circulation stroke is associated with prolonged door-to-needle time. Int J Stroke 2013; e-publisert 22.3.2013.

6. Indredavik B, Fjærtoft $\mathrm{H}$, Ellekjær $\mathrm{H}$ et al. Norsk hjerneslagregister. Årsrapport 2013.

www.stolav.no/no/HF/s/i/MRS/

Norsk-hjerneslagregister/Nyheter/

Arsrapport-2012/125363/ (27.4.2015)

7. Sundseth A, Faiz KW, Rønning OM et al. Factors related to knowledge of stroke symptoms and risk factors in a norwegian stroke population. J Stroke Cerebrovasc Dis 2014; 23: 1849-55.

8. Martin-Schild S, Albright KC, Tanksley J et al. Zero on the NIHSS does not equal the absence of stroke. Ann Emerg Med 2011; 57: 42-5

9. Kuruvilla A, Bhattacharya P, Rajamani K et al. Factors associated with misdiagnosis of acute stroke in young adults. J Stroke Cerebrovasc Dis 2011; 20: 523-7.

10. Sarikaya H, Arnold M, Engelter ST et al. Outcomes of intravenous thrombolysis in posterior versus anterior circulation stroke. Stroke 2011; 42: $2498-502$

Mottatt 1.4. 2015, første revisjon innsendt 20.4 2015, godkjent 27.4. 2015. Redaktør: Liv-Ellen Vangsnes.

Publisert først på nett. 